\title{
Pre-defined competency level based instructional design model for learning Anatomy in an undergraduate medical curriculum
}

\author{
Abeykoon, I. ${ }^{1}$, Fernando, L. ${ }^{1}$, Fernando, A. ${ }^{1}$, Weerasooriya, $T^{1}{ }^{1}$, Chandratilake, M. $^{2}$
}

\begin{abstract}
The paper presents a competency based instructional design model to teach gross Anatomy in an undergraduate medical course. The main objectives of the presented instructional design model is to allow space for identification of finer demarcations for expected competencies while allowing the students to possess a broader understanding of the discussed areas under each competency level. Here the traditional semester will be split into three competency levels and within each competency level the entire region expected to be discussed will be presented. However, the first competency level will discuss the given area superficially with details being introduced during second and third competency levels. The center of focus as well as teaching learning modalities will also evolve with increasing competency levels making the presented instructional design model a more dynamic than a static approach.
\end{abstract}

Key words: Medical education, Anatomy, Competency based education, Higher education, Educational model

\section{Introduction}

Anatomy undoubtedly forms the basis of any medical curricula as well serves a strong component for good clinical practice. However, literature pertaining to anatomy education is increasingly reporting of a deterioration of anatomy knowledge not only among undergraduate students but also among clinical practitioners (Kaufman 1997; Shaffer 2004; Older 2004; Anon 2005).

The authors herewith propose a novel platform for organizing competency level based anatomy teaching whereby the understanding of anatomy is allowed to evolve within the student based on pre-defined competency levels. The proposed approach enables the student to develop a strong core knowledge via a teacher centered, didactic commencement and ends in a complete student centered, clinical based approach

${ }^{1}$ General Sir John Kotelawala Defence University, Sri Lanka.

${ }^{2}$ University of Kelaniya, Sri Lanka.

Corresponding Author: Isuru Abeykoon

Email: isuruabeykoon@kdu.ac.lk allowing for application and synthesis of new knowledge based on the already laid strong foundation.

\section{The approach}

The model presented herewith is an attempt to cater for the need for identifying more finer thresholds of competencies in learning anatomy while allowing the student to develop a broad and a more functional perspective of anatomical structures learnt. The presented model comprises of three predefined competency levels under which gross anatomy can be explored. Competencies for each level are defined such that at the end of any given competency level, the student will possess a holistic understanding of a learnt functional unit appropriate of his/her competency level. Each competency level identified herewith is designed to perceive this broader anatomical picture whereby it substantially rid the student of the need of self-amalgamation.

The core learning competencies identified in this approach are:

1. Enumerate the broader structural and functional perspective of anatomical structures/regions examined with clinical relevance 
2. Demonstrate understanding of three dimensional anatomical arrangement and related anatomical concepts at a minimum level sufficient for good clinical practice

3. Discuss significance of detailed anatomy for functional interpretations and advanced clinical practice

Several "Major Competencies" (MC) are identified under each "Core Competency"(CC) while each $\mathrm{MC}$ is further elaborated by "Ground competencies" (GC) (Table 1). The gradual course of a student through increasing competency levels will enable him/her to add required details to the broader picture whereby a deeper understanding is generated. The model can also be perceived as a more dynamic than a static approach wherein its center of focus as well as teaching learning methodologies evolve in its course through different competency levels.

Each competency level described herein is defined in terms of two aspects namely "content" and "center of focus". The "content" describes the knowledge/skills that are expected to be gained by the student at the end of a given competency level. A number of criteria has been identified in defining "content" for a given competency level and are discussed below.

Criteria for identifying "content" for each competency level.

The criterion identified herewith allows for assignment of both theory knowledge as well as expected demonstrable skills to the three major competency levels identified.

\section{a. Can the content stand its own}

Gross anatomical structures, structural features and facts/relations which can be comprehended as well as described with no or minimal involvement of other structures will be classified under basic competency levels (Table 1).

\section{b. Functionality}

Here, gross anatomical structures with significant functional value will be introduced at early competency levels. An example would be the lateral pectoral nerve as compared with the musculocutaneous nerve. The latter with significant nerve innervation to the anterior compartment of the arm requires to be introduced at an early competency level while the lateral pectoral nerve innervating the pectoralis minor can be introduced at a later stage.

\section{c. Clinical relevance}

Structures with significant clinical relevance requires to be introduced at an early competency level while those which are rarely encountered in the clinical setting can be introduced much later. An example from the brachial plexus would be the long thoracic nerve as compared to nerve to subclavius. Long thoracic nerve damage leads to winged scapula quite easily appreciated during a clinical examination as compared to the latter. Table 1 layouts an example from shoulder region indicating how each of the content is distributed in the competency levels based on the aforementioned criteria.

\section{Defining teaching learning methodologies}

The dynamic nature of the proposed approach is also reflected in the modes of teaching learning methodologies employed. Commencing from a more teacher centered mode of deliverance the teaching methodology is gradually shifted toward the student with increasing competency level. It is expected that such a transition would allow space for the student to get accustomed faster from a teacher centered approach with which he is familiar to a student-centered approach. During latter stages of competency levels where more detailed anatomy is explored the approach assumes a more student-centered focus. Thus, competency level I which is identified as a more teacher centered approach makes a gradual transit towards a fully student-centered approach on reaching competency level III. The teaching learning methodology will also undergo a similar transition reflecting the change of center. Early competency levels as stated would involve direct lectures/video presentations and viewing of prosected specimens allowing for core knowledge development. This mode will soon transit towards guided dissections/tutorials and finally towards self-directed dissections/clinical practicals/clinical case presentations which are complete student oriented approaches (Table 1 ). The transition also allows the students to develop a substantial core knowledge of anatomy prior to dissections and thereby is expected to save a considerable amount of time spent on dissection allowing space for student to develop more in depth understanding of regional anatomy during the dissection course.

It needs to be born in mind that the proposed approach is a mere framework which could be adopted by curricula following different teaching practices. The approach presented does not provide guidelines on identification of 
competencies. Thus, it is an institutional task to determine the degrees of integration. Once decided, the framework can be adapted to layer the content. The stated examples are those for a traditional curriculum with modifications to include a greater degree of vertical integration.

Table 1: Core, major and ground competencies as identified for upper limb with relevant teaching learning methodologies

\begin{tabular}{|c|c|c|c|c|}
\hline $\begin{array}{l}\text { Competency } \\
\text { level }\end{array}$ & $\begin{array}{l}\text { Core } \\
\text { competency }\end{array}$ & $\begin{array}{l}\text { Major } \\
\text { competencies } \\
\text { (identified for } \\
\text { part of upper } \\
\text { limb) }\end{array}$ & $\begin{array}{l}\text { Ground competencies } \\
\text { (identified for rotator cuff } \\
\text { muscles) }\end{array}$ & $\begin{array}{l}\text { Teaching/learning } \\
\text { methodologies }\end{array}$ \\
\hline $\mathrm{I}$ & $\begin{array}{l}\text { Enumerate the } \\
\text { broader structural } \\
\text { and functional } \\
\text { perspective of } \\
\text { anatomical } \\
\text { structures/regions } \\
\text { examined with } \\
\text { clinical relevance }\end{array}$ & $\begin{array}{l}\text { Explains basic } \\
\text { movements of } \\
\text { upper limb } \\
\text { using bones, } \\
\text { joints and } \\
\text { muscles } \\
\text { involved }\end{array}$ & $\begin{array}{l}\text { Describe the three-dimensional } \\
\text { arrangement of rotator cuff } \\
\text { muscles with general/common } \\
\text { origins and insertions and } \\
\text { explain its role in mobility and } \\
\text { stability of the glenohumeral } \\
\text { joint } \\
\text { Clinical relevance } \\
\text { Test for action of rotator cuff } \\
\text { muscles }\end{array}$ & $\begin{array}{l}\text { Lectures/Prosected } \\
\text { specimen } \\
\text { observation }\end{array}$ \\
\hline II & $\begin{array}{l}\text { Demonstrate } \\
\text { understanding of } \\
\text { three-dimensional } \\
\text { anatomical } \\
\text { arrangement and } \\
\text { related } \\
\text { anatomical } \\
\text { concepts at a } \\
\text { minimum level } \\
\text { sufficient for good } \\
\text { clinical practice }\end{array}$ & $\begin{array}{l}\text { Describe the } \\
\text { three- } \\
\text { dimensional } \\
\text { anatomical } \\
\text { arrangement of } \\
\text { the pectoral, } \\
\text { shoulder } \\
\text { regions and } \\
\text { axilla and } \\
\text { explain how } \\
\text { the stated } \\
\text { structural } \\
\text { arrangements } \\
\text { can be related } \\
\text { to normal } \\
\text { function and in } \\
\text { clinical practice }\end{array}$ & $\begin{array}{l}\text { Describe the three-dimensional } \\
\text { arrangement of rotator cuff } \\
\text { muscles, their origins/insertions } \\
\text { and explain their significant } \\
\text { anatomical relations } \\
\text { e.g relations to the joint } \\
\text { capsule, nerves, blood vessels } \\
\text { and other muscles } \\
\text { Clinical relevance } \\
\text { Evaluation of } \\
\text { musculoskeletal problems (e.g. } \\
\text { rotator cuff tear or tendon } \\
\text { rupture) }\end{array}$ & $\begin{array}{l}\text { Tutorials/Guided } \\
\text { dissections }\end{array}$ \\
\hline III & $\begin{array}{l}\text { Discuss } \\
\text { significance of } \\
\text { detailed anatomy } \\
\text { for functional } \\
\text { interpretations } \\
\text { and advanced } \\
\text { clinical practice }\end{array}$ & $\begin{array}{l}\text { Describe } \\
\text { detailed } \\
\text { anatomy of the } \\
\text { pectoral, } \\
\text { shoulder } \\
\text { regions and } \\
\text { axilla and } \\
\text { explains } \\
\text { implications to } \\
\text { function and } \\
\text { clinical practice }\end{array}$ & $\begin{array}{l}\text { Describe detailed anatomical } \\
\text { relations of the rotator cuff } \\
\text { muscles } \\
\text { e.g bursae, fascia, } \\
\text { ligaments(coracohumeral) } \\
\text { Clinical relevance } \\
\text { Execution/evaluation of imaging } \\
\text { studies } \\
\text { (e.g. ultrasound) }\end{array}$ & $\begin{array}{l}\text { Clinical } \\
\text { practicals/clinical } \\
\text { case presentations } \\
\text { and self-guided } \\
\text { dissection }\end{array}$ \\
\hline
\end{tabular}




\section{References}

Anon., (2005). The rise and fall of anatomy. British Medical Journal Career Focus 330, 255-256.

Kaufman, MH., (1997). Anatomy training for surgeons - a personal viewpoint. Journal of the Royal College of Surgeons of Edinburgh. 42, 215216.
Older J., (2004). Anatomy: a must for teaching the next generation. Surgeon 2, 79-90.

Shaffer K., (2004). Teaching anatomy in the digital world. New England Journal of Medicine. 351, 12791282. 